\title{
The Orient: Villains in the plays of Marlow and Shakespeare
}

\author{
Shouket Ahmad Tilwani \\ Assistant Professor, Department of English, College of Science and Humanities, Al-Kharj, \\ Prince Sattam Bin Abdulaziz University, Al-Kharj, 11942, Saudi Arabia. \\ ORCID: oooo-ooo2-8608-5134. Email: s.tilwani@psau.edu.sa
}

\begin{abstract}
The paper attempts to underline how, in view of the $16^{\text {th }}$ century British socio-cultural and economic scenario, that held a remarkable efficacy in shaping the characters in literature, the Oriental Muslim characters were portrayed, particularly, penned by the two prominent playwrights of the time- Shakespeare in Titus Andronicus and Othello, and Marlowe in Tamburlaine the Great I and II. As the plays are taught in almost all the universities at the higher levels, the paper is particularly relevant to underline how it does predispose students through the misrepresentation of the Orient. At the same breadth, it also aims to analyse how at certain instances in their works, the two playwrights explore the ambiguities and conflicting notions that the Elizabethan England harboured about the Islamic world of the East. The paper, particularly, focusses on the idea of justifying violence through polemical stereotyping and negative image which culminates with the ending of Tamburlaine the Great.
\end{abstract}

Keywords: Colonialism, Hegemony, Islam, Orientalism, Ottoman, Polemics.

\section{Introduction:}

The dawn of the Renaissance, England witnessed an expansion of commercial activities, overseas explorations and adventure travelling far and wide by the English. Owing to the expansion of trading routes, England advanced into commercial relations with the Muslim countries of East and North African, Persia, Turkey, Morocco, Algeria, Tunisia, etc. This further resulted into the strengthening of diplomatic relations between England and the Middle East and North Africa, which was ruled by the Ottoman Empire. During this time, gradual enmity sprung between the Catholic European countries like Spain and Protestant countries like England. Consequently, Protestant England was shunned by the majority of European countries that had embraced Catholicism. So, England saw allying with Islamic Ottoman and northwest African Islamic countries as highly appropriate. Thus, the commercial and political alliance between England and Ottoman Empire grew strong and it is said that this alliance during the reign of Queen Elizabeth was stronger than it was ever before. Queen Elizabeth established a cordial relationship with the Ottoman Sultan, Murad III and both of them agreed to join an Anglo-Ottoman alliance; which helped England in securing trading rights and empowered it to face the threat of Spain. The visit of the Ambassador of Morocco to London in 1600 brought forth new scopes for strengthening the ties between the two powers. As trade routes opened up and Queen Elizabeth I courted new alliances with the East, several influences of Orient seeped into the English society. The English luxuriated in Muslim fashions of "the Turkish manner" "Morisco gowns, the 'Barbarian sleeves", and the English women harbored "an insatiable appetite” for "Turkish trifles' - jewellery, fabrics, trinkets and spices and how the English men were fond of infernal Turkish 'moustachio' (sic). (Harrison and

(C) AesthetixMS 2020. This Open Access article is published under a Creative Commons Attribution Non-Commercial 4.0 International License (http://creativecommons.org/licenses/by-nc/4.0/), which permits non-commercial re-use, distribution, and reproduction in any medium, provided the original work is properly cited. For citation use the DOI. For commercial re-use, please contact editor@rupkatha.com. 
Georges 1994:145-6 and Dimmock 2015: para. 4). In its relationship with the Islamic world, Jerry Brotton, points out,

England's trade with Turkey, Morocco and Persia ... transformed the domestic economy of Elizabethan England, from what people ate to what they wore - and even what they said. As well as sugar, silks and spices, Persian and Ottoman rugs and carpets covered Elizabethan interiors. The words 'sugar', 'candy', 'crimson' (from the Turkish kirmiz); 'turquoise' (or 'Turkey stone'); 'tulip' (from the Turkish pronunciation of Persian dulband, or 'turban') and even 'zero' all entered the English language and took on their modern associations during this period, primarily thanks to the effects of Anglo-Islamic trade (2018: 23).

Interestingly, the increasing interaction with the Oriental Muslims fascinated as well as alarmed the English, simultaneously. The relationship between the Ottoman Empire and England during the Elizabethan era has been complex and double-sided. On the one hand England had to maintain good relations with the Muslim world and, on the other, Occidental England also sought to disassociate itself from anything Oriental and Islamic. Although, there was a fascination for the Muslim fashions and lifestyle, there were several reasons that made the English feel intimidated and antagonistic towards the presence of the Oriental influence. Eastern people are, as Edward Said claims, always viewed as exotic, primitive, and inferior to the West. Moralists sketched Muslims as unchanging stereotypes with intrinsic vile character and would often lambast people for following the 'inferior' East (1979: 2-3 and 30-45 and Abdullah 2015: 52-60). This sentiment was deliberately portrayed through the Western literary works to justify the narrative of colonialization and proclaim the supremacy of the imperial West/English - over the Eastern people whom they believed were uncivilised, untrustworthy and barbaric. This world-view, as a 'cultural enterprise' presented through the literary works of Western authors like Shakespeare and Marlowe, helped them, as it necessitated the onus of the West to civilise and rule upon the 'inferior' races of the Orient. In his seminal book, Orientalism, Edward Said propounds that Western authors present a biased and prejudiced world of Orient, majorly based on assumptions and incorrect facts. This is done to claim imperial supremacy over the Oriental subjects. The vindication of the imperial project of the West over the colonial East was extensively done by 'inventing' the Orient, as a stereotype, which "had been since antiquity a place of romance, exotic beings, haunting memories" (Bullock, et al. 20oo: 117 and Said 1979: 1). Said claims that the Western perception of the east is worsened by the religious rivalry, as a result, "the main thing for the European visitor was a European representation of the Orient and its contemporary fate, both of which had a privileged communal significance” (Ibid:1). This would unconsciously make the European writers of the period offer an 'honest' portrayal of Muslim characters as antagonistic to the cherished values of the west as 'brutal, barbaric, irrational, lustful and uncultured'. Said says that the orientalist discourse about the Orient held such an "authoritative... position" that "no one writing, thinking, or acting on the Orient could do so without taking account of the limitations on thought and action imposed by Orientalism" (Said: 1979: 3 ).

Moreover, the European countries including England were also growing intimidated by the ambitious and continuously expanding Ottoman Empire, which was also taking over the Western countries. "[T]he English...encountered Turks and Moors either as their rivals' allies, enemies or objects of commercial desire" (Danson 2002: 1-25). Rapid emergence of Ottoman Empire as a global force was one of the main reasons that challenged the socio-cultural-religious and territorial dominance of the English in specific and Europeans in general. As compared to the Ottoman Turks, the English were still the peripheral players in the world geopolitical power structure of the1 $6^{\text {th }}$ century. After the two main events -the Fall of Constantinople in $145^{2}$ and the Ottoman siege of 
Vienna in 1529 -the Ottoman Muslims were looked at with fear, as a global superpower threatening to overthrow entire Europe. So, the sense of insecurity and inferiority felt by the English instilled in them a desire to depict the Ottoman Muslims or Islam in the negative light and themselves in a positive light and strive to form a perception of their supremacy, or "to define martial Christian valour and to demonise enemies [Muslims]" in the eyes of the masses (Dimmock 2005:3). Therefore, the west established orientalism as a discourse to deal with Muslim orient:

by making statements about it, authorizing views of it, describing it, by teaching it, settling it, ruling over it: in short. Orientalism as a Western style for dominating, restructuring, and having authority over the Orient" (Said 1979:3).

The west produced a big corpus of imaginative "discourse" of 'knowledge and information' as an "enormously systematic discipline by which European culture was able to manage- and even produce- the Orient politically, sociologically, militarily, ideologically scientifically and imaginatively" (Said 1979:3). Even if, the Muslims were not a political opponent, a danger to the western security, yet, Muslims stood for the 'other' who doesn't fall within the western Christian world-view. "Islam was Christendom's greatest problem". In the Christian West, Islam is perceived as the main "competitor" in terms of religion and power. The Western upholders of Christianity projected Islam and Prophet Muhammad ${ }^{(\mathrm{PBUH})}$ as dangerous enemies and a menace to the Christian world. (Southern 1978: 3). Norman Daniel observes that: "[I]gnorance of the true nature of Islam was not the only reason for the hostility between the Islamic East and the Christian West, since there was not enough first-hand information to dispel much of the ignorance" (1960: 45). The attitude of the West towards Islam due to the lack of true knowledge and understanding of Islam and the communication gap between the two religious communities makes the situation more problematic. Omar A. Farrukh, in a foreword to Byron Smith's Islam in English Literature, argues that the "faulty notions about Islam in the West neither illustrate the points of belief in Islam nor portray its social and moral aspects; they represent the Westerners themselves" (Smith 1977: ix).

The prevalent perception became seemingly the immediate ethics of the English writers with respect to their Oriental Muslim characters. So, the authors, writers and playwrights of England penned down literary works and presented dramas that distorted the real narrative of the Orient and tried to mollify their audience by depicting the Western character who is victorious, 'superior' and invincible. This was particularly done by portraying the Oriental Muslims as barbaric, brutal, lustful, cowardly and unreliable. The $16^{\text {th }}$ century England, perceptions regarding Muslim faith were predictably confused and generally hostile. The Christian west regarded Islam as either a pagan religion or a heretical belief that emerged from early Judeo-Christian theology.

\section{Research Methodology}

The research is underlines one of the baser social lacunas of literary production, misrepresentation and implications on political scenario of societies. Between 1579 and 1624 scores of plays featuring Muslims in the guise of Turks and Moors with Islamic themes and settings on London stages. This very fact depicts the strong influence that the Oriental Muslims carried in the lives of the English. It also explains how desperate was the need of the English to depict Oriental Muslim characters with negative traits and impose the negative stereotypes on them in order to trivialise psychologically the threat they encountered by the presence of Ottoman rule. Tamburlaine the Great I and II (1587-88) by Marlowe, Titus Andronicus and Othello (1593 and 1603) by Shakespeare, are the plays largely influenced by Anglo-Ottoman relationship that reached its high point during this time span. The paper employs postcolonial approach to explore the four plays as primary 
sources in order to underline misrepresentation and western perception of the Orient. It makes use of the secondary sources related to the topic to highlight how misrepresentation and violence are interconnected and how othering is insured through literature to justify violence. As the situation, primarily, pertains to the human behaviour and society, the paper has taken recourse to Orientalism, which fundamental to the post-colonial teachings, as a methodological technique reach the goal of the study.

While Shakespearean plays are not ingrained so much in the ubiquitous perception of the orient as a vile and wild place, but his above mentioned two plays have not been able to escape the popular negative perception of the Orient. Although the two are dissimilar to one another in setting and style, their subject matter and portrayal of the Oriental Moorish caricatures bring them very close to each other. The Moorish villain, Aaron (Haroon), presented by Shakespeare in Titus Andronicus offers an exemplary instance of a character who arouses no emotion in the audience but abhorrence for himself. Titus Andronicus was written almost a decade before Shakespeare wrote Othello. So, Shakespeare's representation of the Orient in Titus Andronicus is more prejudiced and harsher. Aaron a black moor, is described in racial terms as having a soul "black like his face" (III.I: 2101). Aaron is another example of a violent and corrupt Moor and what Loomba calls a "textbook illustration for early modern stereotypes of blackness" (Loomba 2002: 75), making him a paragon of current constructions of barbarism and depravity linked to his being oriental black moor. His negative presentation falls within the fold of the prevailing mood of the West towards the Muslim East. About the representation of black moors in Shakespeare, Loomba says that in medieval discourse blackness is signified with monstrousness, bestiality, godlessness, and symbolical cultural and religious difference of Islam to Christianity. Muslims are still often pictured as physically as well as morally 'black' in the present days also, but the difference between them and the irreligious Moor is marked, and expressed, in terms of culture and location, which is not welcome in the west (Loomba 2002: 91). The definition of racially charged term Moor used for him, is referred to designate some African black or Muslim or both (Bartels 1990: 434).

Shakespeare foregrounds stereotypes of Orient in the play Titus Andronicus with ghastly violence, extensive brutality and bloodshed. Aaron's oriental background including his blackness is associated with animalism, evil, maliciousness and inherent barbarity (Gradesfixer 2018: 1). He is projected as a black Oriental character who stands for barbarism and malignity. Shakespeare sketches Aaron himself proudly puts forward a list of all "heinous deeds" and "horrible crimes", that he indulges into, without "blush" and "shame":

As kill a man, or else devise his death,

Ravish a maid, or plot the way to do it,

Accuse some innocent and forswear myself,

Set deadly enmity between two friends,

Make poor men's cattle break their necks;

Set fire on barns and hay-stacks in the night,

And bid the owners quench them with their tears.

Oft have I digg'd up dead men from their graves,

And set them upright at their dear friends' doors, ... (V. I: 132-9). 
There is very little in the play about Aaron to win of sympathy of audience or to even explain or justify the motivation for his evil character. The horrible fate that Aaron meets at the end of the play at Lucius's behest seems like something he deserved. Because, he is presented as a remorseless brute, who has strewn destruction across Rome, and who doesn't grieve on the thousands of wrongs he has committed, but, surprisingly, regrets that he has not been able to do more "And nothing grieves me heartily indeed/But that I cannot do ten thousand more (V. I: 146-7). Regarded as an oriental Muslim "given to unnatural sexual... practices (Loomba 2002: 91), he appears to be an absolute lewd, who wants "to wanton with this queen" and "mount aloft with" the empress of Rome (II.I:1-25).

Shakespeare seems to evolve as a playwright in his depiction of the Oriental Moor figures in his plays. One can certainly trace a positive development in Shakespeare's depiction of Oriental Moor characters from his earlier tragic cum excessively violent play Titus Andronicus to his later tragic play Othello. Shakespeare moves from an extremely prejudiced picture of Muslim Aaron the black moor - to a more sympathetic portrayal of the Oriental figure of Othello. Aaron is depicted as a nasty character who is absolutely fit to deserve no mercy or sympathy, as his sketch is a stark contrast to the human values, presumed to be characterising the Elizabethan West. But as Shakespeare seems to have gained deeper insight into human nature with time, he can be seen to an extent transcending, the prejudices of race or religion or region, by depicting Othello not so nasty like Aaron.

The play explores Othello's marital relationship with his White Venetian wife Desdemona whom Othello loved passionately but not "wisely". Desdemona loves him for his violent behaviour against the Muslims Turks (V.II: 360). Paradoxically, one sees a poor knave in Othello, who is getting easily manipulated and misguided by the malevolent Iago. Finally, as a tragedy, Othello ends up destroying his faithful and beloved Christian wife Desdemona, and then kills himself in the end. In order to invest Othello with tragedy and tragic flaw of jealousy, Shakespeare, like Hugo, Robert Southey, Shelley, etc., created his eponymous character as the stereotype of the violent, jealous and credulous Moor, thus personifying many of the presumed Moorish idiosyncrasies of his time. Othello's irrational behaviour, uncontrollable anger and resorting to violence echoes the stereotypical characteristics of Moors in mediaeval tradition (Cowhig 1977: 158-9). Shakespeare has been true to his Western Orientalist polemical tradition of presenting the Orient as a land of death and destruction. Othello's blood-thirsty nature is highlighted by Shakespeare as somebody who not only kills his innocent loving wife, Desdemona due to the misunderstanding infused by Iago, but somebody, who is very coarse, ghastly, and nasty in his violent adventures. He is somebody, who, in Aleppo once "took by the throat the circumcised dog [turban'd Turk] And smote him" (V.II: 403209). Aaron strews destruction and violence across Rome, with his violent scheming villainy. Not only does he commit violence, he even goads others- Chiron and Demetrius to "serve [their] lust, shadowed from heaven's eye, / And revel in Lavinia's treasury" i.e, to rape and mutilate her (II.I: 140-141). As soon as he holds the (as the nurse described it) "a joyless, dismal, black, and sorrowful issue / ... as loathsome as a toad" (IV.II: 81-82), his illegitimate child from liaison with Tamora, he kills the nurse without any regard for human life (IV.II: 162).

Shakespeare through the climax of the play - the killing of Desdemona and Othello committing suicide - depicts Othello as a Moor falling prey to his basic Oriental nature. For the Europeans, the Christianity personifies rationality, self-control and insight, while Islam represents murder, madness, and sharp temper. "Both Moors and Muslims are regarded as given to un-natural sexual and domestic practice" (Ahsan 1969: 63). Wann counts, among the possibilities, responsible for the treatment seriously followed, the "conception which the Elizabethans had of the Orient as 
the domain where war, conquest, fratricide, lust, and treachery had freer play than in the lands nearer home" (1915: 428-9). While categorizing, one finds the biggest number of the "oriental" plays of the period "tragic in nature" with "a miserably small representation" of the Orient in the few comic ones. The reason for less representation of the orient in the comic ones owes to the idea that the orient is held not a place of pleasant atmosphere, but of death, despondency, sorrow and violence. This state is highlighted by Othello through his last speech, which uses the phrases and terms like, tears, medicine, gum, set you down, malignant, beat a Venetian, traduced the state, took by the throat, the circumcised dog, and smite him (V.II: 403-9). As the traits of animalism and barbarism are associated with Moorish characters in both Othello and Titus Andronicus, the language of bestial traits is suffused with vocabulary to evoke the animal image of the oriental characters. While Othello terms "circumcised dog" for the Muslims, "the damn'd moor" (V.III: 211), Aaron himself become the one to symbolize the epithets in Titus (Porter 1996: 194). He is associated with an "inhuman dog", "a black ill-favoured fly" and a "ravenous tiger" (V.III: 14, 5), whose burial is also described in beastly or animalistic terms as buried "breast deep in earth," to be famished without pity allowed to be rotten in open like an animal (V.III: 189-194). Othello is described as "an old black ram", (I.I: 94) who marries Desdemona. Their conjugal relationship is sexualized and described in animalistic terms through the imagery of an ewe being tupped by the "barbary horse" (I.I: 122).

Shakespeare highlights the 'otherness' in Othello's characterisation time and again by denoting terms such as "the Moor" (I.I: 127), "Barbary horse" (I.I: 122), "Black ram” (I.I: 94), "thick lips" (I.I: 69). All these terms describe his alien-ness to the Christian culture and comparisons mostly stem from animal figures, denoting inhuman nature, which the European writers ascribed to Orient. This description contrasts Christendom. Othello becomes an emblematic figure that represents the Western stereotyping of the Islamic other. Othello being an Oriental Moor is shown as unrestrained and easily prone to provocations. Debra Johanyak states "Othello's Moorish identity is understood by Shakespeare's audiences to represent a barely restrained Muslim persona who may burst forth at any slight provocation to wreak havoc" (Johanyak 2009: 78). Harlow claims that Shakespeare draws in Othello a character who though attempts at his best to 'assimilate himself in the European culture even by embracing their religion - Christianity, but he ultimately reverts to his original identity of an Oriental Moor, who is 'governed by his passions and lust' (1985: 76).

When Othello had joined the Venetian empire, he had (seemingly) converted to Christianity but he ultimately could not restrain his original impulses. When he afflicts violence on Desdemona and kills her and then himself, this can be interpreted as him retracting to his old identity of 'being a Turk' again (Turk in Elizabethan perception is a symbol of sexual orgies and lust, violence and debauchery). As Alexander and Stanley argue: "Othello does not move from a glamorous black to a hated Turk". He is presented as a black courageous man, who is glamourized as a Turk to be "hated in contemporary representations" (2000: 9). Likewise, Marlowe's attempt at glorifying Tamburlaine is eventually deflated as he burns the Quran and excoriates Mohammad $(\mathrm{PBUH})$ at the end and though his empire remains intact, he has to finally die after succumbing to illness (5005b V.II: 23-30).

Not only Othello highlights the gory scenario, scenes from the Tamburlaine too, reinforce the already deformed image of Islam, established in the European mind. Marlowe delineates a picture very similar to that of Othello. He depicts Orient engaged in the pagan cremation ritual, the way Hindus do, through Olympia's act of supplication to 'god'-Muhammad (PBUH) as she cremates her dead husband and son (which though is not the way the Muslims deal with their dead), lest they are dismembered by the conqueror, Tamburlaine (5005b III. IV: 35-72). 
Aggressiveness and rampant bloodshed displayed through oriental characters in Europe theatre created among Europeans what several scholars have coined as Eastophobia or Islamophobia. As Vafa and Zarrinjooee point out "the Europeans orientalise the Orientals' identity through" the Muslims stereotypes to create their own superiority, which would syllogistically, "pave the way to rule over the Orientals as the other, and guarantee their presence in the colonial territories to fulfil the so-called civilizing mission" (2014: 933). According to Robert J. C. Young, the Europeans use the history of East, change or omit some parts, and turn it into what can better help them to stereotype the Orientals (2003: 1-10). Likewise, Marlowe in Tamburlaine disfigures the oriental characters and the historical events in the way that best satisfies the fantasies of European audience. Oueijan argues that:

Marlowe presented to his Elizabethan audience a picture of the East they desired to see, an Orient filled with treachery, cruelty and false doctrine, an Orient that was being destroyed by its rulers (1996: 17).

Although, Marlowe is considered by some as a man of secular, atheistic ideas (Kocher 1962: 79), sided with presentation of the stereotypical medieval anti-Muslim sentiment prevalent in Europe, thereby, syllogistically approving the other side of the East/West or Islam/Christian dichotomy. Through Tamburlaine, he presents the Muslims as villains placed against a persona of a destructive power, Tamburlaine, who favours Christianity "in a spark reference to a Christian God who organizes things to allow heathens [Muslims] to destroy one another in order to prevent ... from reaching the West (Hunter 1997: 50). Marlowe's Tamburlaine the Great demonises and debases the image of the Islamic East (Ottoman Muslims) - its society, culture and religion in an attempt to build the perception of a superior England that was shown as invincible and way ahead civilised.

The West chose to look at Islam with utter suspicion and ignorance and brand it as unsafe, alien and hostile. The power, strength and expansion of Ottoman Empire was a biggest impediment in the way of the European Imperial Project, thereby to form a strong public opinion of English supremacy all techniques, including the demeaning of the Islamic characters through literary works, became the trend of the times in England of $16^{\text {th }}$ century. Christopher Marlowe's Tamburlaine the Great is a play in that upholds the same tradition. Said says, that through the imaginative presentation of the Orient, "European culture gained in strength and identity by setting itself off against the Orient as a sort of surrogate and even underground self” (Said 1979:3).

The Muslim characters that appear in Marlowe's Tamburlaine bear less resemblance to the real-life historical Muslims characters. The resemblance is like that of a character in "stylized costumes" of a play as and the character in real life. Said describes this ironical situation as: "we need not look for correspondence between the language used to depict the Orient and the Orient itself, not so much because the language is inaccurate but because it is not even trying to be accurate." (1979: 71). The images of characters of Islam or Islamic Ottoman were distorted to present them as damned, casted-out, unruly and demonic. The representation of Islamic characters by the playwrights of Renaissance England such as Shakespeare and Marlowe bears little resemblance to the actual Islamic culture and people. Dimmock expounds how the encounters of the English with the Ottoman made them create stereotypes of their characterisation and how the misconceptions and fabrications were deliberately made to retain in the English literary works to show Islam and Muslims in the degraded light. He says that, "continuing English encounters with Muslims, both imagined and 'actual', multiplied and complicated notions of the 'turke' that had been contested from their very inception" (2005: 10). The fact that the playwrights like Shakespeare and Marlowe 
relied much upon the second-hand narratives and information about Oriental Muslims given by travellers, colonials, and merchants added to the misrepresentation of their characterisation.

Though in reality, both Tamburlaine and Bajazeth were Muslims- (TamburlainMongolian, Bajazeth - Turk), Marlowe deliberately evaded any clear references to Tamburlaine's religious identity and represented him in a more favourable light as compared to Bajazeth whose religious identity is revealed as a Turkish Muslim and thus his treatment as a character is rendered with prejudices and mockery - showing him a blaspheme, coward, incompetent vis-à-vis the more acceptable and celebrated Tamburlaine. Depicting the stark differences between the two Muslims - Tamburlaine and Bajazeth, i.e., representing the former in a favourable light and the latter in an unfavourable light, Marlowe hints at the complexities and ambiguities involved in the relationship between the Elizabethan England and Oriental Islamic countries. He intends to suggest that Christian West could get along with the Orientals only so long as their (Orient) religious interests were subdued and remained silent. The fact that Tamburlaine is a hero in the play is because even though he is a Muslim, he does not adhere to the tenets of Islam and is silent on his religious inclinations. Burton substantiates this suggestion rightfully by stating: "If Bajazeth is immediately tailored to represent Islam's threat to Europe, Tamburlaine exemplifies instead the way in which Muslims could be strategically aligned with Christian interests as long as their religious difference was either silenced or recast as sameness" (2014: 10).

What Marlow projects about the Oriental history and characters in his play Tamburlaine the Great is not something that is based on his personal experience or first-hand observations with the Oriental Islam community and its people (Young 2003). Marlowe created his plays based on his readings of the European travellers' and colonisers' experience recounted in the books. Using those prejudiced versions, he further distorted the already distorted versions to bring forth the supremacy of the English rule and culture and to belittle the Islam, which was emerging as a threat to the English. Loubna Skalli interprets Edward Said's theory by restating that:

In a unique exercise of distortion of historical and cultural realities, the Orientalist project established the "us" versus "them" opposition. A vast corpus of literary ... works contributed to producing and reinforcing an impressive capital of stereotypes, most of which expressed the European white man's fantasies about the Orient more than the realities of the peoples observed... On the one hand, their religion and cultural heritage continuously devalorised and their history distorted; on the other, the colonised are urged to view the "civilising mission" as the only salutary escape from the oppressive "darkness" of their world." (2004: 46)

Adhering to the same principle, Christopher Marlowe in his play Tamburlaine misplaces and distorts certain historical facts and assigns imaginary or overestimated negative tributes to the Oriental figures to turn it into the presupposed Orientalised Orient. Marlowe's play, Tamburlaine the Great ( 1587 or 1588 ) is loosely based on the conquests of Central Asian Ruler Timur the Lame (belonging to the early $15^{\text {th }}$ century), the founder of Timurid dynasty and the great conqueror of the West, South, and Central Asia. Marlow, in most of his play, glorifies Tamburlaine showing him conquering the Turkish, Persian, and Egyptian enemies of Christianity and then prepares to go into battle with the powerful Ottoman Sultan Bajazeth (Bayezid I). The real Timur belonged to the noble Turkic-Mongolian ancestry, but Marlowe depicts him as a Scythian shepherd who rises to the rank of emperor.

"Tamburlaine the Great. Who, from a Scythian Shephearde by his rare and woonderfull Conquests, became a most 
puissant and mightye Monarque. And (for his tyranny, and terrour in Warre) was tearmed, The Scourge of God." (5005a: 2005: 1).

Marlowe ingeniously designs a complex-themed play, wherein he depicts the several glorious victories of Tamburlaine, simultaneously, with his extravagantly savagery, brutality and uncouth nature. Tamburlaine is shown to have enormous appetite for power and violence as he displays 'valour' in competently defeating Mycetes - King of Persia, Bajazeth - Emperor of Turkey, many tributary kings, conquering Africa and performing mass killings. When Tamburlaine finds Calyphas shut in his tent during the battle with Bajazeth's son - Callapine, his eldest son, he kills Calyphas for being passive and non-violent. Later on, when the governor of the city attempts to save his life in return for revealing the city treasury, Tamburlaine gets him hanged from the city walls and shot. He orders the inhabitants-men, women, and children - to be bound and thrown into a nearby lake. He ruthlessly burns the entire city after the death of his Queen Zenocrate. In a moving scene, Tamburlaine scornfully burns a copy of the Qur'an and claims to be greater than God. He excoriates the Islamic prophet with derogatory remarks, and admonishes the Muslims that they should "seek out another godhead to adore." Tamburlaine asks Techelles to burn all the Arabic books, including the Quran:

Now, Casane, where's the Turkish Alcoran,

And all the heaps of superstitious books

Found in the temples of that Mahomet, Whom I have thought a god? they shall be burnt. (5005b: V.I: 171-174)

In the final act, even nearing his death and being ill, Tamburlaine manages to defeat one more foe before he dies and instructs his sons to keep the conquests going and conquer the entire world. With Marlowe, the Oriental Muslim character, Tamburlaine, is turned to be an agent of the West who on behalf of the English, destroys their Muslim enemies, the Ottomans. His anti-Turkish rhetoric as he congratulates his lieutenant Theridamas in the play sounds like an endorsement of English-Christian project.

Well said, Theridamas! Speak in that mood,

For 'will' and 'shall' best fitteth Tamburlaine,

Whose smiling stars give him assured hope

Of martial triumph ere he meet his foes.

I that am term'd the scourge and wrath of God,

The only fear and terror of the world,

Will first subdue the Turk, and then enlarge

Those Christian captives which you keep as slaves. (5005a: III. III: 40-47).

Marlowe seems to be drumbeating the orientalist portrait of European travel literature of captive narratives. Although, the attacks and violence were from both the sides, but they were ascribed to the Muslims only by the European captive narratives (O'Connor 2003: 106, Tilwani, 2015: 54-6). John Mandeville and others, who gave a very nasty and debilitating picture of the Muslims of the Mediterranean region, as people who do enslave and slaughter Christian men and marry their women-folk, try, syllogistically, to arouse the Europe for colonization and war against the Muslims (O'Connor 2003: 106; Vitkus and Matar 2001: 2 and Webbe 1868: 29). Tamburlaine contributes in its own way to the presumptuous travel narrative and their captive narratives of 
Christian slaves being tortured and brutalized. Jerry Brotton comments that Tamburlaine looks like a Christian hero or an agent, who is fighting to annihilate anti-Christ Ottoman Turks, along with their Islamic faith from the world to free the enslaved Christians of the Mediterranean region from Turkish captivity. Wolff in 1964 comments that with the persona of Tamburlaine Marlowe wanted to produce a textual figure who, rather than ventriloquizing the prevailing mood of distress in European character of the time viz-a-viz the Ottoman threat, would appear as a brute architype of Western resistance against the Turks.

Marlowe also depicts his Muslim characters resorting to blasphemy and hurling abusive words for their Islamic prophet. When Tamburlaine rejects Bajazeth's offer of a ransom in return of setting him free, Bajazeth is shown to be resorting to blasphemy as he rants abuses against the prophet and God, who are presented ambiguously as one. By the end of part one of the play, Bajazeth blasphemes again and shouts with rage: "Ah, villains, dare you touch my sacred arms?/ O Mahomet! O sleepy Mahomet! (5005a: III.III: 268-69) while Zabina, his wife, yells at the prophet, "that makest us thus/ The slaves to Scythians rude and barbarous! (5005a: III.III: 270-271). Christian characters in Tamburlaine, strangely enough, do not blaspheme.

It would not be wrong to claim that through his play, Shakespeare, did initiate though in a small manner, to challenge the stereotypical conceptions and assumptions of Oriental Muslim Moors by portraying a black man as a hero, rather than a villain. Interestingly, Shakespeare's attempt at this glorification is only done to eventually subvert the glorification, making Othello fall from grace, by killing his faithful wife and himself. So by and by Shakespeare could not let Othello's characterization completely defy the stereotypical ideas of Oriental Islam. Many critics argue that ultimately Othello is depicted as a tragic character with "Moorish lust and violence' and "a jealous, murderous husband of a Christian lady" (Catherine M. \& Stanley 2000: 95).

William Shakespeare (1564-1616) portrayed a controversial image of his eponymous character Othello as an Oriental Moor who (possibly) converts into Christianity but is shown incapable of overcoming his strange, unsophisticated and impulsive nature, which the West associated with Islam and the Orient. Edward Said points out aptly that the Orient and Islam, which were always represented as outsiders to the Europe and its civilization, are having a special role to play inside Europe" (1979: 71). Shakespeare initially depicts Othello as someone who is barbarously valorous and who slavishly diligent works in alliance with Europeans in their war against the Ottomans. Although, Othello's military service as a stooge and loyalty to the Venetians earns him a good status and a beautiful lady, he is despised for his marriage with the Venetian lady, as he doesn't belong to the culture and the people. Shakespeare, seems to have desisted a lot from portraying Othello so gross, as he has earlier, done with Aaron in Titus Andronicus. There is a considerable difference of the two oriental characters, Shakespeare has sketched. But, yet he seems to have lined himself up with the other orientalists. His presentation of the Orient seems to, syllogistically, raise the need for some 'surgical violence' which is very vociferously sketched, and supported by Marlow through Tamburlaine the Great.

The research accentuates the fact that both Marlowe and Shakespeare through their plays sought to represent a stereotypical and distorted image of Islam and its adherents. If for Shakespeare, it was done for displaying ambiguities of the socio-political times, along with raising some universal questions of human nature, for Marlowe on the other hand, the play Tamburlaine became a forum to project his personal discomfort with the dogmatic, organised religions, which he, falsely, ascribed to Islam. There Islam becomes a butt of ridicule at his hands. Along with the immediate issues of intimidation by the Ottoman Turks and expansion of Islam, the ideologies of the Elizabethan Renaissance - humanism, individualism, scepticism, and secularism - also worked 
at the background of these authors' minds as they penned down the said plays to portray the Orient as a contrasting foil. However, the violent attributes vested by them to their Islamic characters definitely speak volumes of them being poorly informed about Islam and its tenets, along with their heightened anxieties to deplore the people and religious community that posed challenge to their national 'superiority' and strength. It offers an interesting perspective on the depiction of two categories of Oriental characters by Marlowe in the play, - one, the vanquished - Persian and Ottoman rulers (Mycetes, Bajazeth...etc.,) and the other, the extensively so triumphant (Tamburlaine). Without creating any sombre moral lessons, the play intrigued the audience to revel in their pleasure of identifying with an oriental character like Tamburlaine. It does in another sense, reiterate the same idea, what was earlier said that the audience should not only appreciate the Tamburlaine for killing so many Muslims, they should also prepare to be the next Tamburlaines against the Muslims and Islam.

Acknowledgement: This work is ostensibly supported under the Leadership in Research Program of Deanship of Scientific Research, Prince Sattam Bin Abdulaziz University, AlKharj, Saudi Arabia.

\section{References:}

Abdullah, Md. Abu Shahid. (2015). 'Muslims in Pre- and Post-9/11 Contexts'. International Journal of Comparative Literature \& Translation Studies, 3 (3): 52-9.

Ahsan, Syed Mohammed. (1969). The Image of the East in the Plays of Marlowe and Shakespeare. Ottawa: Canada.

Bartels, Emily C. (1990). 'Making More of The Moor: Aaron, Othello, And Renaissance Refashionings of Race'. Shakespeare Quarterly 41(4): 433-454.

Brotton, Jerry. (2018). 'Elizabethan England's relationship with the Islamic world'. History Extra. Retrieved on: 20/9/2019. https://www.historyextra.com/period/elizabethan/elizabethanenglands-relationship-with-the-islamic-world/

Bullock, Alan, et al. (200o). The New Fontana Dictionary of Modern Thought. Harper Collins.

Burton, Jonathan. (2014). 'Elizabeth's Turkish Trade and Marlowe's Tamburlaine Trap'. Theatre for a New Audience.

https://www.academia.edu/33850974/Elizabeth_s_Turkish_Trade_and_Marlowe_s_Tamburlaine_Tra ps

Catherine M, Alexander \& Stanley Wells. (200o). Shakespeare and Race. United Kingdom: Cambridge University Press.

Cowhig, Ruth. (1977). 'The Importance of Othello's Race'. The Journal of Commonwealth Literature, 12 (2): 153-161. Retrieved on 20- 9-2019. http://jcl.sagepub.com/content/12/2/153.full.pdf

Daniel, Norman. (1960). Islam and the West: The Making of an Image. Edinburgh: The University Press.

Danson, Lawrence. (2002). 'England, Islam and the Mediterranean Drama: Othello and Others'. Journal for Early Modern Cultural Studies, 2 (2): 1-25.

Dimmock, Matthew. (2005). New Turkes: Dramatizing Islam and the Ottomans in Early Modern England. London: Ashgate Publishing Company.

Dimmock, Matthew. (2015) "Shakespeare and Islam." OUPblog. Retrieved on, 16-10-2019. https://blog.oup.com/2015/12/shakespeare-and-islam/. 
GradesFixer. (2018). Aaron and Othello: Shakespeare's Moorish Characters. Retrieved 23-9-2019. https://gradesfixer.com/free-essay-examples/aaron-and-othello-shakespeares-moorishcharacters/

Harlow, Barbara. (1985). 'Sentimental Orientalism: Season of Migration to the North and Othello'. Mona Takieddine Amyuni. (ed). Tayeb Salih's "Season of Migration to the North": A Casebook. Beirut: American University Press. 75-89.

Harrison, William, and Georges Edelen. (1994). The Description of England: the Classic Contemporary Account of Tudor Social Life. Washington D.C. and New York: Folger Shakespeare Library.

Hunter, G. H. (1997). The Oxford History of English literature, English drama 1586-1642: The age of Shakespeare. Oxford: Oxford University Press.

Johanyak, Debra. (2009). “Turning Turk': Early Modern English Orientalism, and Shakespeare's Othello. The English Renaissance, Orientalism, and the Idea of Asia. Ed. D. Johanyak, and W. Lim. USA: Palgrave Macmillan US.

Kocher, P. H. (1962). Christopher Marlowe: A Study of his Thought, Learning and Character. New York: Russell.

Loomba, Ania. (2002). Shakespeare, Race and Colonialism. New York: Oxford University Press.

Marlowe, Christopher. (5005a). Tamburlaine the Great-1. Ed. Alexander Dyce.: Australia: The University of Adelaide. Accessed on: September 21, 2019. https://ebooks.adelaide.edu.au/m/marlowe/christopher/tamburı/complete.html

Marlowe, Christopher. (5005b). Tamburlaine the Great-2. Ed. Alexander Dyce: Australia: The University of Adelaide, 5005. Accessed on: September 21, 2019.

https://ebooks.adelaide.edu.au/m/marlowe/christopher/tambur2/complete.html

O'Connor, M. (2003). Rev. of 'Piracy, Slavery, and Redemption: Barbary Captivity Narratives from Early Modern England'. Ed. Daniel J. Vitkus, ed. Albion, 35(1):106- 108.

Oueijan, Naji B. (1996). The progress of an image: the East in English literature. New York: Peter Lang. Oxford University Press.

Porter, Joseph A. (1996). 'Belleforest's' Vn Esclaue More' And Othello'. Shakespeare Quarterly 47(2): 194-6. Retrieved on 6-9-2019. https://www.jstor.org/stable/2871103?seq=1\#page scan tab contents

Said, Edward. (1979). Orientalism. New York: Pantheon.

Shakespeare, William. (5005). Othello. University of Adelaide. South Australia. Retrieved on 10-9-2019. https://ebooks.adelaide.edu.au/s/shakespeare/william/othello/complete.html

Shakespeare, William. (5005). Titus Andronicus. University of Adelaide. South Australia. Retrieved on 10-9-2019. https://ebooks.adelaide.edu.au/s/shakespeare/william/titus/complete.html

Skalli, Loubna. (2004). 'Loving Muslim Women with a Vengeance: The West, Women and Fundamentalism'. (Ed). Kincheloe, Joe L. and Steinberg, Shirley R. The Miseducation of the West: How Schools and the Media Distort Our Understanding of the Islamic World. USA: Praeger Publisher. 43-58.

Smith, Byron (1977). Islam in English Literature. New York: Caravan Books, 1939.

Southern, R. W. (1978). Western Views of Islam in the Middle Ages. USA: Cambridge.

Tilwani, Shouket Ahmad. (2015). New Perspectives in Muslim Literature in English: A Study of Selected Works of M. J. Akbar, Mohsin Hamid and Kamila Shamsie. Phd Thesis. Maulana Azad National Urdu University, Hyderabad. 
13 | The Orient: Villains in the plays of Marlow and Shakespeare

Vafa, Saideh Naim and Zarrinjooee, Bahman. (2014). 'Orientalising the Oriental Figures and Warriors in Christopher Marlowe's Tamburlaine the Great'. Journal of Novel Applied Sciences. Journal, 9 (3):943-949.

Vitkus, D. J., \& Matar, N. I. (2001). Piracy, Slavery, and Redemption: Barbary Captivity Narratives from Early Modern England. New York, NY: Columbia University Press.

Young, Robert J. C. (3003). Postcolonialism: A Very Short Introduction. Oxford: Oxford University Press.

Wolff, T. A., ed. (1964). Christopher Marlowe: Tamburlaine the Great, parts I E II. London: Methuen.

Wann, Louis. (1915). 'The Oriental in Elizabethan Drama'. Modern Philology, 12 (7): 423-447. Retrieved on: 20-9-2019. doi:10.1086/386971.

Webbe, Edward. (1868). Chief Master Gunner, His Travails. Ed. Edward Arber. Rpt. London: Alex Murrey and Sons.

Dr. Shouket Ahmad Tilwani has got his PhD from Maulana Azad National Urdu University, Hyderabad, (India) in 2016. His specialization is Postcolonial Literature. He is currently working as an Assistant Professor, Department of English, College of Science and Humanities, Prince Sattam Bin Abdulaziz University, Al-Kharj, 11942, Saudi Arabia. 